\title{
SLOPES OF THE RAILWAYS OF THE MOSCOW AS AN ECOLOGICAL NICHE FOR RARE AND ENDANGERED PLANT SPECIES
}

\author{
Barinov Andrey, Bochkin Vassiliy, Vinogradova Yulia*
}

N.V. Tsitsin Main Botanical Garden of Russian Academy of Sciences, Moscow, Russia

Received: 16. 2. $2019 \quad$ Revised: 30. 10. $2019 \quad$ Published: 30. 11. 2019

The role of the railways slopes as an ecological niche for rare and endangered plant species was reflected on the example of the Moscow metropolis. A comparative analysis of the information from the database on the flora of the railways in Moscow (Barinov, 2017) and data from the Red Book of Moscow (Red Book..., 2011) was carried out. The database was created on the basis of herbarium materials stored in the Herbarium of the Main Botanical Garden (MHA) and Herbarium of the M.V. Lomonosov Moscow State University (MW). It includes information on 480 natural and 606 alien species. The railways were considered in a broad sense (including railway tracks, platforms, stations, adjacent slopes and cuvettes, exclusion zones). The length of the Moscow railways in the old borders of the city (until 2012) is more than $300 \mathrm{~km} .480$ aboriginal species was registered on the railway, 34 (7\%) of them are considered as rare species and were included in the 'Red Book of Moscow'. Two species Botrychium lunaria and Allium angulosum have been receive category 0, four Antennaria dioica, Nonea pulla, Dactylorhiza fuchsii, and Thymus marschallianus - category 1. Labels of all herbarium specimens are given. Some railway's populations of rare species are quite stable. Thus, Allium angulosum on the meadow near the railway station Bojnja, and Thymus marschallianus on the railway embankments with meadow-steppe plant communities in front of Butovo station exist here more than 20 years. The record belonged to Thymus $\times$ loevyanus: this hybridogenic taxon grows in the same locality - on the railway embankments with meadow steppe cenoses near the railway station Butovo since 1946 (more than 65 years). Since in Moscow even mosaic meadow communities are extremely rare, it is necessary to use all measures to maintain the remnants these natural phytocenoses, the disappearance of which is the main threat to the reduction of natural biodiversity. The task is to develop measures to preserve indigenous species on the roadside, in spite of the prevailing practice of covering slopes with rolling lawns. The proportion of natural meadow species can be increased with a suitable mode of mowing and abandoning of herbicides and possibly also by artificial seeding of native plants. In a metropolis, such an approach will be the only possible way to increase the ecological significance of roadside habitats that will be able to assume the function of ecological corridors not only for native plants but also insects and even, possibly, animals. It is concluded that in large cities, railway slopes can make up for the lack of suitable habitats for both natural vegetation in general, and for rare and endangered plant species.

Keywords: biodiversity, endangered plant species, Moscow, railway, rare plants, Red Book

*Corresponding author: Vinogradova Yulia, N.V. Tsitsin Main Botanical Garden of Russian Academy of Sciences, Botanicheskaya, 4, 127276 Moscow, Russia

$\triangle$ gbsad@mail.ru 


\section{Введение}

Луга, даже антропогенно нарушенные, являются биотопами, находящимся под угрозой уничтожения. В Москве и Московской области многовидовых лугов большой площади не осталось совсем, лишь в редких случаях можно найти мозаичные сообщества. Из-за постоянно усиливающегося землепользования доля придорожных местообитаний в общей площади полуестественной растительности быстро растет. Типичные луговые виды растений, приспособленные к непрерывному выпасу или скашиванию, которые сохраняют «открытой» окружающую среду, начинают произрастать в альтернативных местообитаниях по обочинам дорог. Хотя растительность обочин считается ценотически ненасыщенными сообществами (Kopecky and Hejny, 1974; Schaffers and Sýkora, 2002), они, тем не менее, могут быть богаты видами.

В 1980-х годах в Европе признана важность обочин в поддержании биоразнообразия и разработаны меры для сохранения на них богатых видами сообществ (Parr and Way, 1988; Cale and Hobbs, 1991; Jefferson et al., 1991; Harrington, 1994; Allem, 1997; Tikka et al., 2001). Доказано, что в сильно фрагментированном городском ландшафте железнодорожные откосы могут выполнять функцию экологических коридоров для аборигенных видов (Penone et al., 2012). Признавая экологическое значение придорожных местообитаний, европейские ботаники проводят инвентаризацию синтаксонов, встречающихся вдоль обочин дорог. В Нидерландах, например, на обочинах железных дорог выявлено 15 полуестественных богатых видами растительных сообществ, относящихся к 11 союзам, входящим в 10 ассоциаций, причем все эти сообщества произрастали и за пределами придорожных местообитаний. Аналогичные исследования проведены в Бельгии (Schaffers and Sýkora, 2002) и Финляндии (Tikka et al., 2000).

Снижение доли естественных фитоценозов является главной угрозой для многих редких и исчезающих видов сосудистых растений. И откосы железных дорог могут быть экологической нишей для этих видов. Эти местообитания сходны с сухими и мезофитными лугами, и их растительность поддерживается косьбой и удалением дающих тень древесных растений. Разумеется, откосы железных дорог не являются полноценной заменой полуестественным лугам. Но присутствие луговых видов на обочинах может быть повышено за счет подходящего режима скашивания и отказа от использования гербицидов, что будет способствовать формированию на обочинах дорог естественной растительности.

В Великобритании некоторые дорожные откосы рассматриваются в качестве объектов особого научного интереса (Parr and Way, 1988), а в Голландии 8 \% придорожных растений классифицируются как редкие или довольно редкие виды (Tikka et al., 2001). В Финляндии $4 \%$ исчезающих на национальном уровне видов регулярно встречаются на обочинах, например, Campanula cervicaria L., Dianthus arenarius L. и Hypericum montanum L. (Tikka et al., 2001). В Богемии (Чехия) в этот перечень входят Dactylorhiza majalis (Rchb.) Hunt et Summerh. и Gentianopsis ciliata (L.) Ma (Jandová et al., 2009). 
Сходные тенденции отмечены и в России. В Самаре и Самарской области (Ivanova, 2008) на железной дороге произрастают луговые (Centaurea jacea L., Dianthus pratensis Bieb.,), степные (Astragalus danicus Retz., Salvia tesquicola Klok. and Podeb., Stipa capillata L.) и лесные (Corylus avellana L., Pulmonaria obscura Dumort., Euonymus verrucosa Scop.) растения. Отмечены и редкие виды (Centaurea ruthenica Lam., Astragalus zingeri Korsh., Stipa capillata L. и др.). На железнодорожных насыпях южной части Приволжской возвышенности (в границах Саратовской области) также найдены (Skvortsova and Berezutskyi, 2008; Ryibakova, 2008) популяции охраняемых растений (Chartolepis intermedia, Astragalus cornutus, Glycyrrhiza glabra, Iris halophila, Stipa pennata, Adonis wolgensis, Dodartia orientalis и др.). На железнодорожных насыпях Куйбышевской и Южно-Уральской железных дорог в Башкирии выявлено 7 видов, занесенных в Красную книгу Республики Башкортостан: Glycyrrhiza korshinskyi, Linaria altaica, Rosa pimpinellifolia, Stipa korshinskyi, Stipa lessingiana, Stipa sareptana, Thermopsis schischkinii (Husainova, 2016).

В связи с этим целью настоящей работы является выявление роли откосов железных дорог Москвы как экологической ниши для редких и исчезающих видов природной флоры.

\section{Материал и методика}

\section{Объекты исследования}

Изучена флора железных дорог Москвы, протяженность которых в старых границах мегаполиса (до 2012 г.) составляет более 300 км. Железные дороги рассматривались в широком смысле (включая железнодорожные пути, платформы, станции, прилегающие склоны и кюветы, зоны отчуждения).

\section{Методы исследования}

Проведен сравнительный анализ сведений из базы данных по флоре железных дорог г. Москвы (Barinov, 2017), и данных Красной книги г. Москвы (Krasnaya Kniga..., 2011). База данных создана на основе гербарных материалов, хранящихся в Гербарии Главного ботанического сада (MHA) и Гербарии МГУ им. М.В. Ломоносова (MW), в нее включены сведения по 480 природным и 606 чужеродным видам (Vinogradova et al., 2017). В отдельных случаях для уточнения сведений использовались и некоторые литературные источники (Ignatov et al., 1990; Adventivnaya flora.., 2012). Все гербарные этикетки цитируются в работе без редакторской правки.

\section{Результаты и дискуссия}

Аналогично данным, полученным в других регионах, на железной дороге Москвы в сохраненных полуестественных луговых сообществах произрастают редкие и уязвимые виды растений. Отмечено 34 вида, включенные в Red Book of Moscow (2011). Два вида: Botrychium lunaria и Allium angulosum имеют категорию 0, четыре вида: Dactylorhiza fuchsii, Nonea pulla, Thymus marschallianus и Antennaria dioica имеют 
категорию 1, тринадцать видов имеют категорию 2, двенадцать видов имеют категорию 3 и три вида имеют категорию 5 (Таблица 1).

Таблица 1 Виды из Красной Книги г. Москвы, обнаруженные на железных дорогах Table 1 Plant species are included in the 'Red Book of Moscow' which grow at the railway

\begin{tabular}{|c|c|}
\hline Категории редкости видов & Наименование видов \\
\hline Категория 0 (исчезнувшие виды): & Botrychium lunaria (L.) Sw., Allium angulosum L. \\
\hline $\begin{array}{l}\text { Категория } 1 \text { (виды, находящиеся под } \\
\text { угрозой исчезновения): }\end{array}$ & $\begin{array}{c}\text { Antennaria dioica (L.) Gaertn., Nonea pulla (L.) DC., } \\
\text { Dactylorhiza fuchsii (Druce) Soo, Thymus marschallianus } \\
\text { Willd. }\end{array}$ \\
\hline $\begin{array}{l}\text { Категория } 2 \text { (редкие виды } \\
\text { или малочисленные виды с } \\
\text { сокращающейся или сократившейся } \\
\text { численностью) }\end{array}$ & $\begin{array}{l}\text { Astragalus glycyphyllos L., Veronica teucrium L., } \\
\text { Lithospermum officinale L., Geranium robertianum L., } \\
\text { Campanula bononiensis L., Allium oleraceum L., } \\
\text { Festuca valesiaca Gaud., Filipendula vulgaris Moench } \\
\text { (= F. hexapetala Gilib.), Listera ovata (L.) R. Br., Phleum } \\
\text { phleoides (L.) Karst., Viola tricolor L., Thymus } \times \text { loevyanus } \\
\text { Opiz. (=Th. marschallianus Willd. } \times \text { Th. pulegioides L., } \\
\text { Thymus } \times \text { glabrescens Willd.), Anthyllis vulneraria L. } \\
\text { (= A. macrocephala Willd.= A. schiwereckii (DC.) Blocki) }\end{array}$ \\
\hline Категория 3 Уязвимые виды & $\begin{array}{c}\text { Astragalus danicus Retz., Polygonum bistorta L. (= Bistorta } \\
\text { major S.F. Gray), Fragaria viridis (Duch.) Weston, Iris } \\
\text { pseudacorus L., Campanula rotundifolia L., Campanula } \\
\text { persicifolia L., Trollius europaeus L., Dactylorhiza incarnata } \\
\text { (L.) Soo, Anthemis tinctoria L., Eryngium planum L., Steris } \\
\text { viscosa (L.) Rafin. }\end{array}$ \\
\hline
\end{tabular}

Категория 4

Виды неопределённого статуса

Категория 5 Восстановившиеся виды на железных дорогах Москвы не выявлены

Campanula patula L., Convallaria majalis L., Leucanthemum vulgare Lam.

\section{Категория 0 (исчезнувшие виды)}

Botrychium lunaria (L.) Sw. (гроздовник полулунный). В Московской области изредка встречается во всех её частях, кроме Заокской. На территории, ныне занимаемой Москвой, в XIX- начале XX вв. вид отмечали в Раменках, по р. Сетуни, в Хорошеве, между сёлами Братцево и Спасское, в Петровско-Разумовском и Останкине (Krasnaya Kniga..., 2011).

В 1990 г. на железной дороге в трансформированной долине р. Нищенки этот вид был найден 'Москва. Малая Окружная ж.д. Юго-Восточный сектор, 800 м от сорт.ст. Андронова к сорт. ст. Лефортово по склону неглубокой ж.д. выемки. Колония. 30.07.1990. В.Д. Бочкин' (MНА). После 2000 г. ни в данном пункте, ни где-либо ещё не наблюдался.

Allium angulosum L. (лук углова́тый, или мыши́ный чесно́к). В Московской области довольно редок, известен из южных и восточных районов. На территории, ныне занимаемой Москвой, в XIX веке отмечен на Ключиках в Перове, под Симоновым монастырём, в Верхних Котлах и на р. Москве близ Серебряного Бора. В прошлом 
чаще произрастал в естественных местообитаниях - на пойменных заливных лугах, а позднее приобрёл черты редкого заносного вида. В последние десятилетия встречались единичные экземпляры на открытых нарушенных склонах, луговинах вблизи железных дорог, приречных лугах и песках. В 1980 г. найден у пересечения канала им. Москвы с Ленинградским шоссе, в 1989-1991 гг. - у ж.д. ст. 'Бойня' (Krasnaya Kniga.., 2011). Вид в этом местообитании довольно устойчив, поскольку более чем через 20 лет обнаружен там же 'Москва. Юго-Восток. Малая окружная ж.д. Середина

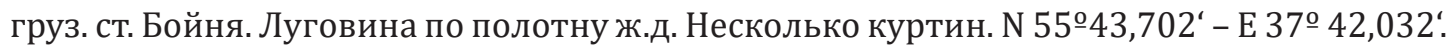
11.07.2013. В.Д. Бочкин, С.Р. Майоров (МНА)؛

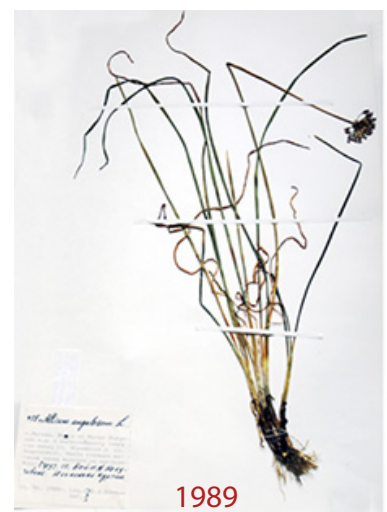

1989
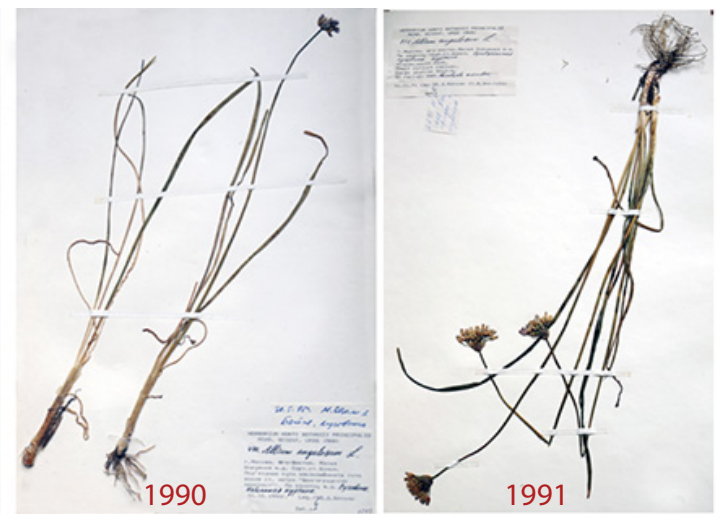

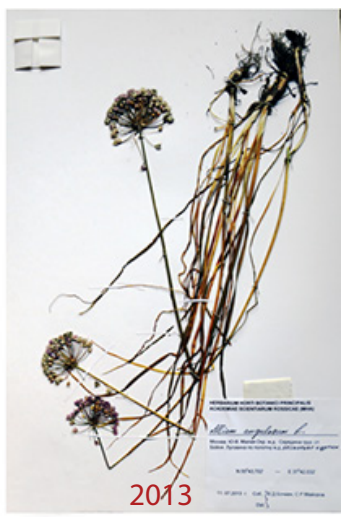

2013

Рисунок 1 Гербарные сборы Allium angulosum на грузовой станции Бойня

Figure 1 Name and description of the image Herbarium specimens of Allium angulosum at the cargo station Bojnia

\section{Категория 1 (виды, находящиеся под угрозой исчезновения)}

Antennaria dioica (L.) Gaertn. (коша́чья ла́пка двудо́мная). В Московской обл. до недавнего времени вид считался обычным во всех районах, но в ближнем Подмосковье резко сократил численность и распространение. На территории, ныне занимаемой Москвой, в XIX - первой половине XX вв. кошачья лапка была распространена достаточно широко, указывалась, например, для Лосиного Острова, Сокольников, Кунцева, ПетровскоРазумовского и Останкина. В 1980-2000 гг. в пределах МКАД известны лишь единичные находки, из них только 3 на природных территориях - в окрестностях ЗнаменскогоСадков, Черепкове и на Крылатских холмах (Krasnaya Kniga.., 2011). Произрастал этот вид и по железной дороге: 'г. Москва, в кустарнике возле насыпи Белорусской ж.д. (совская ветка) между ст. Рабочий поселок и кольцевой автодорогой. 25.05.1980. М.С. Игнатов; г. Москва. Малая окружная ж.д. Юго-восточный сектор. 800 м от сорт. ст. Андроновка к сорт.ст. Лефортово. Луговина по склону неглубокой ж.д. выемки. 30.07.1990. В.Д. Бочкин‘ (МНА). Кошачья лапка росла также в единичных экземплярах в Коломенском, но после 2003 г. там не найдена. В 2009 г. популяция кошачьей лапки в долине р. Сходни в Куркине насчитывала 8 цветущих и не менее 10 вегетирующих экземпляров (Krasnaya Kniga.., 2011). 
Nonea pulla (L.) DC. (нонея тёмно-бурая, дурнушка тёмно-бурая, кривоцвет тёмный, монашка тёмно-бурая, нонея бурая, нонея тёмная). В Московской обл. известен во всех ботанико-географических р-нах, кроме Верхне-Волжской низменности. Обычен в южн. части Подмосковья, в северной встречается редко и преимущественно во вторичных местообитаниях. На территории, ныне занимаемой Москвой, в конце XIX в. нонею регистрировали близ Серебряного Бора и в Выхине, но лишь как заносный вид на ж.д., в 1980-1990 гг. - также на железной дороге: 'Москва по полотну Окружной ж.д. возле пересения ее с Октябрьской ж.д. 10.06.1981. М.С. Игнатов; Москва, около полотна Окружной ж.д. возле стадиона им. Ленина. Единично. 25.05.1981. М.С. Игнатов; Москва, Курская ж.д., около ст. Текстильщики, на насыпи ж.д. 20.05.1987. В.Д. Бочкин; Москва, Северо-Запад. Малая окружная ж.д. Сорт. ст. Серебряный бор. По полотну ж.д. Одно растение. Венчик темно-красный. 08.06.1990. В.Д. Бочкин (МНА). В последнее время найдена в Коломенском на Дьяковском участке в виде малочисленных локальных популяций и единичных экземпляров (Krasnaya Kniga..., 2011).

Dactylorhiza fuchsii (Druce) Soо (пальчатокоренник Фукса). В Московской обл. обычен и встречается повсеместно. На территории, ныне занимаемой Москвой, в XIX - первой половине XX вв., возможно, этот вид отмечали в Лосином Острове, Битцевском лесу, на Воробьёвых горах, в Кунцеве, Всехсвятской роще, Петровско-Разумовском, Останкине, хотя ряд указаний может относиться к пальчатокоренникам пятнистому, балтийскому или гебридскому. В 1950-1980-е гг. этот (или похожий) вид зарегистрирован только на территории МСХА им. К.А.Тимирязева в 1958 и 1962 гг., а также в ГБС (Krasnaya Kniga.., 2011). Встречен он и по железной дороге 'Москва, юг. Павелецкая ж.д. Луговина по полотну ж.д. около пл. Бирюлево-Товарная. Луговина. Одно растение. 20.06.1991. В.Д. Бочкин' (MHА). В последнее время обнаружен в пойме р. Котловки в 2009 г., на юге Битцевского леса в 2008 г., в Зап. Знаменском карьере в 2008-2009 гг., пойме р. Сетуни в Жуковке в 2009 г., на Щукинском п-ве в 2007, 2009 и 2010 гг., долине Машкинского ручья в Куркине в 2009 г. (Krasnaya Kniga.., 2011).

Thymus marschallianus Willd. (тимьян Маршалла). Встречается в южной части Московского региона. На территории, ныне занимаемой Москвой, вид отмечали в 1865 г. в Н.Котлах, в 1985 г. в Коломенском и в 1996 г. близ Троекуровского пруда, за МКАД - в окрестностях Знаменского-Садков. В 1987 г. найден у ж.д. ст. Бутово (Красная книга.., 2011), через год собран там же: 'Насыпь с лугостепной растительностью справа у ж.д. на Симферополь перед ст. Бутово. Юг Москвы. Р/н Бутово-Знаменского. 06.06.1988. В.Куваев' (МНА). В этом же месте вид обнаружен и через 10 лет: «Юг Москвы. Окрестности Знаменского района. Насыпь Курского направления Моск.ж.д. справа 0,5-0,8 км перед ст. Бутово. Лугостепная растительность. 11.06.1997. В. Куваев» и еще через 10 лет «Юг Москвы вне МКАД. Справа от Курской ж.д. <1 км перед ст. Бутово. Высокая насыпь со степненно-луговой растительностью. 11.06.2007. В. Куваев, Б. Когут; Лугостепь на высокой насыпи справа от М-Курской ж.д. 1 км перед ст. Бутово. 29.05.2008. В. Куваев, Ю. Насимович» (МНА). Таким образом, на ж.д. насыпи с луговостепной растительностью крупная популяция Thymus marschallianus стабильно 
растет уже около 20 лет. В 2001-2010 гг. подтверждено произрастание этого вида и на Дьяковском городище в Коломенском (Krasnaya Kniga.., 2011).

\section{Категория 2. Редкие виды или малочисленные виды с сокращающейся или сократившейся численностью}

Виды этой категории встречаются на железных дорогах гораздо чаще, чем предыдущие группы, и популяции их более многочисленны.

Allium oleraceum L.'Москва, север, Савеловская ж.д., 1км от пл. Окружная к пл. Дегунино. Болото у основания ж.д. насыпи. Луговина по краю болота, среди ив. Большая колония. 22.06.1992. В.Д. Бочкин' (МНА).

Anthyllis vulneraria L. 'Москва. Близ пл.Петровско-Разумовская. По ж.д. откосу. 29.08.1966. М. Лутонина»; 'Москва, Октябрьская ж.д. Левая колея. В 400м от проспекта Мира (пл. Рижская) к пл. Останкино. По полотну ж.д. Луговина. 16.07.1990. В.Д. Бочкин'; 'Москва, юг, Павелецкая ж.д.. По полотну ж.д. Бирюлево-Пассажирская. Луговина. Большая колония. 20.06.1991. В.Д. Бочкин'; 'Москва. Юго-запад. Киевская ж.д. 900 м от пл. Москва-сортировочная к пл. Матвеевская (возле пересечения с р. Сетунь). По полотну высокой ж.д. насыпи. Большая колония. 21.06.1991. В.Д. Бочкин' (МНА).

Astragalus glycyphyllos L. 'Москва, вдоль полотна Курской ж.д. между ст.Люблино и Текстильщики. 09.06.1980. Собрал М.С. Игнатов, определил В.Д. Бочкин'; 'Москва, Бирюлевский лес. Южная часть Царицынского лесного массива. На железнодородном

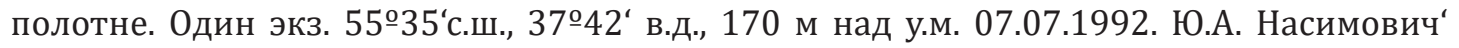
(MHA).

Campanula bononiensis L. 'Москва, Рижская ж.д. 400 м от пл. Рижского вокзала к пл. Дмитровская. Придорожная луговина. Колония. 04.07.1991. В.Д. Бочкин'; 'Москва, Северо-Запад, Рижская ж.д. 700 м от пл. Трикотажная к пл. Павшино. Луговина по склону неглубокой ж.д. выемки. В массе. 10.08.1991. В.Д. Бочкин' (МНА).

Festuca valesiaca Gaud. 'Москва, в зарослях кустарников на ст. Покровская Курской ж.д. 28.06.1980. Алексеев; 'Москва, Киевская ж.д. По полотну грузовой колеи ж.д. станции Москва-сортировочная. Отдельные куртины, рассеяно.06.06.1989. В.Д. Бочкин'; 'Москва. Малая Окружная ж.д. Ветка к мясокомбинату в 700 м от ст. Угрешская к ст. Андроновка. На песке вдоль полотна. Около сорт.ст. Бойня. Большая колония. 11.06.1989. В.Д. Бочкин'; 'Москва, Малая Окружная ж.д. Сорт.ст. Бойня (возле ст.метро Волгоградский проспект). По полотну ж.д. Колония. 04.07.1990. В.Д. Бочкин“; 'Москва. Юго-Запад. Малая Окружная ж.д. 500 м от Новодевичьей набережной к сорт. ст. Воробьевы горы (р-н Лужников). На высокой ж.д. насыпи. По полотну тупиковой ветки. Колония. 12.06.1990. В.Д. Бочкин; ‘ Лугостепь по высокой насыпи справа от М-Курской ж.д., примерно 800 м перед ст. Бутово. 29.05.2008. В. Куваев, Ю. Насимович‘ (МНА).

Filipendula vulgaris Moench 'Москва, юг. Павелецкая ж.д. 100м от пл. Чертаново к пл. Бирюлево-товарная. Луговина по склону ж.д. выемки. Колония.19.06.1991. В.Д. Бочкин' (MHA). 
Geranium robertianum L. 'Москва. Сорт. ст. Моссельмаш Октябрьской ж.д. (в 180 м от пл. Моссельмаш в сторону ст. НАТИ), вдоль полотна ж.д. $55.8603^{\circ}$ с.ш., 37.5330 으.д. Немногочисленная популяция. 05.06.2013. К.Ю. Теплов'; 'Москва, Ю-В Курская ж.д. сорт.ст. Люблино, 100 м от диспетчерской вышки от Москвы. По полотну ж.д. Много.

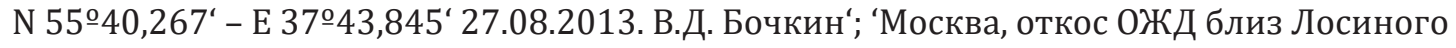
острова и Бермудского треугольника, не менее десятка розеток в условиях легкого затенения подростом деревьев. 23.04.2014. Ю.А. Насимович‘ (МНА).

Listera ovata (L.) R. Br. 'Москва, север. Савеловская ж.д. 1,8 км от пл. Окружная к пл. Дегунино. Болото у основания ж.д. насыпи. Несколько десятков растений. 22.06.1992. В.Д. Бочкин' (МНА).

Lithospermum officinale L. 'Москва, северо-запад. Рижская ж.д. 100 м от пл. Трикотажная к пл. Павшино. Придорожная луговина. В массе. 10.08.1991. В.Д. Бочкин‘ (МНА).

Phleum phleoides (L.) Karst. 'Москва. Северо-Восток. Малая окружная ж.д. По полотну ж.д. около сорт. ст. Ростокино. (возле пересечения с Ярославской ж.д.). 05.06.1990. В.Д. Бочкин; 'Москва, Север. Савеловская ж.д. По полотну сорт. ст. Бескудниково. Одна куртина. 30.06.1992. В.Д. Бочкин' (МНА).

Thymus × loevyanus Opiz. 'Близ ст. Бутово. Травянистый склон к ж.д. 22.06.1946. Ворошилов; ' Юг Москвы. Окрестности Знаменского. Насыпь Моск.-Курской ж.д. справа примерно в 0,5 км перед ст. Бутово. Остатки лугостепной растительности. 08.07.1996. В. Куваев; 'Юг Москвы. Окрестности Знаменского. Насыпь Курского направления Моск. ж.д. справа 0,5-0,8 км перед ст. Бутово. Лугостепная растительность. 11.06.1997. В. Куваев'; 'Юг Москвы. Лугостепь на возвышенности насыпи справа у М-Курской ж.д. перед станцией Бутово. 05.09.2005. В. Куваев; 'Юг Москвы вне МКАД. Справа от ж.д. на Симферополь, примерно в 1 км перед ст. Бутово. Высокая насыпь с лугостепной растительностью. 03.08.2006. Собрал В. Куваев, определил С. Майоров; 'Юг Москвы, вне МКАД. Справа от Курской ж.д., больше чем в км перед станцией Бутово. Высокая насыпь с остепненно-луговой растительностью. 11.06.2007. В. Куваев, Б. Когут; 'Москва. Восточная опушка Северного Бутовского лесопарка. Бутовская лугостепь (склон железнодорожной выемки по направлению к Москве от ст. Бутово). Начало сентября 2012. Собрал - М.В. Островская, определил Ю.А. Насимович' (МНА).

В этом местообитании, как видно из гербарных этикеток (Рисунок 2), данный гибридогенный таксон произрастает уже более 65 лет!

Veronica teucrium L. 'Москва. Павелецкая ж.д. 800 м от пл. Бирюлево-Пассажирская к пл. Булатниково. Придорожная луговина. Колония. 20.06.1991. В.Д. Бочкин'; 'Москва, юг. Курская ж.д. 400 м от ст. Царицыно к пл. Покровская. Придорожная луговина. Колония. 20.06.1991. В.Д. Бочкин; 'Юг Москвы вне МКАД. Справа от М-Курской ж.д., примерно в 1 км перед ст. Бутово. Высокая насыпь с остепненно-луговой растительностью. 11.06.2007. Собрал - В. Куваев, Б. Когут, определил - В. Куваев, Н. Решетникова' (МНА). 
Barinov, A., Bochkin, V., Vinogradova, Y.

Agr.bio.div. Impr. Nut., Health Life Qual., 2019, 281-293

Viola tricolor L. 'Москва. Юго-Восток. Малая Окр. ж.д 400 м от пересечения с Курской ж.д по ветке к платф. Чухлинка Горьковской ж.д. Свалка строительного мусора. Колония. N 55²3,372' E37²43,187'. 25.9.2012. В.Д. Бочкин' (МНА).
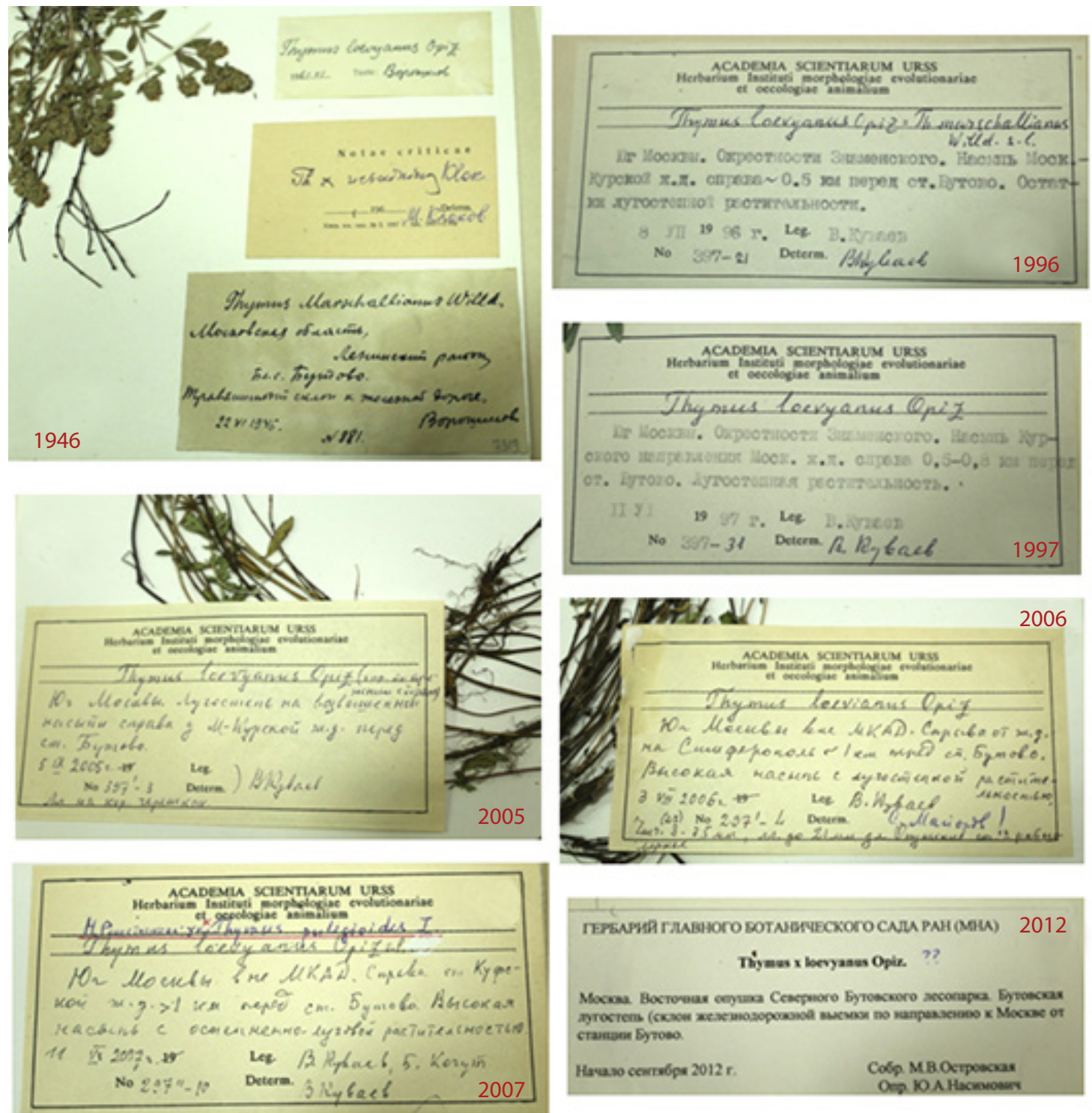

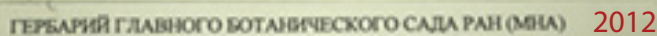

$$
\text { Tigmes } \mathrm{x} \text { beryanus Opis. ?? }
$$

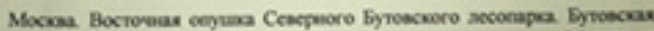

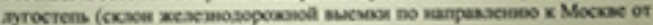
cranan Byoeo.

Havaw cemrobes $2012 \mathrm{r}$.

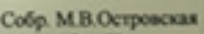

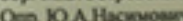

Рисунок 2 Гербарные этикетки, иллюстрирующие стабильное произрастание Thymus $\times$ loevyanus в одном и том же местообитании в течение 1946-2012 годов

Figure 2 Herbarium labels illustrating stable of Thymus $\times$ loevyanus' population in the same habitats during 1946-2012 


\section{Категория 3. Уязвимые виды}

Anthemis tinctoria L. 'Москва. Октябрьская ж.д. Левая колея. Около пл. Рижская. По полотну грузовой колеи. Колония. 16.07.1990. В.Д. Бочкин'; 'Москва, юго-запад. Киевская ж.д. 700 м от пл. Москва-сортировочная к пл. Матвеевская. Луговина по полотну ж.д. Большая колония. 21.06.1991. В.Д. Бочкин'; 'Москва, Дубининская ул., д 63. Заводские ж.д. пути ЗВЧ (Завод Владимира Ильича). Павелецкая ж.д. На сорном месте. Колония. 15.07.2000. В.Д. Бочкин:

Astragalus danicus Retz. 'Москва, близ ст. Петровско-Разумовская. По ж.д. откосу. 20.06.1966, собрал - Дубницкий, определил - В. Макаров'; 'Москва, по откосу насыпи Окружной ж.д. возле стадиона им. Ленина. 04.06.1981. М.С. Игнатов'; 'Москва. Малая Окружная ж.д. По полотну сорт.ст. Андроновка. На луговине. Большая колония. 18.05.1989. В.Д. Бочкин; 'Москва. Север. Малая Окружная ж.д. По полотну тупиковой ветки около сорт.ст.Владыкино (со стороны сорт.ст. Ростокино). Луговина. Колония. 05.06.1990. В.Д. Бочкин'; 'Москва, юго-восток. Малая окружная ж.д. По полотну груз.ст.Бойня. Придорожная луговина. Колония. 06.06.1991. В.Д. Бочкин'; 'Москва, север. Савеловская ж.д. 600 м от пл. Окружная к пл. Дегунино. (возле пересечения с р Лихоборкой) Луговина на склоне высокой ж.д. насыпи. Большая колония. 22.06.1992. В.Д. Бочкин'; 'ЮВАО. Нижегородская улица, возле пересечения с 3-м кольцом вдоль полотна Горьковской ж.д. у пересечения с 3-м кольцом. Придорожная луговина. Одна куртина. 11.10.2008. В.Д. Бочкин'; 'Москва. Юго-Восток. Малая окр.ж.д. 400 м от ТТК по ветке от Бойни к Чухлинке. На вершине высокой ж.д. насыпи. На песке. Куртина. N 55 43,16 - E 42 46. 25.09.2012. В.Д. Бочкин'; 'Москва. Юго-восток. Горьковская ж.д. 700 м от пересечения с Малой окр.ж.д. (сорт. ст. Андроновка) к ст. Серп и Молот. Придорожная луговина. Куртина. N 5544,083 - E 37²42,993. 18.05.2013. В.Д. Бочкин'.

Campanula persicifolia L. «Москва. Курская ж.д., 1.4 км от пл. Битца к пл.Бутово (возле ВИЛРа). Придорожная луговина, по склону ж.д. выемки. Колония. 09.09.1990. В.Д. Бочкин»; «Москва, северо-запад. Рижская ж.д. 700 м от пл.Трикотажная к пл. Павшино. Луговина по склону неглубокой ж.д. выемки. Колония. 10.03.1991. В.Д. Бочкин»; «Москва, север. Савеловская ж.д. 700 м от пл.Бескудниково к пл. Лианозово. По склону ж.д. насыпи. Луговина. Колония. 30.06.1992. В.Д. Бочкин».

Campanula rotundifolia L. 'Москва, Владыкино, между Окружной ж.д. и оградой ГБС. В старых посадках березы по насыпи вдоль ж.д. Колония. 21.07.1986. Собрал - В.Д. Бочкин, определил - В. Макаров'; 'Москва, Малая окружная ж.д., Юго-восточный сектор, 800 м от сорт. ст. Андроновка к сорт. ст. Лефортово. Луговина по склону неглубокой ж.Д. выемки. Большая колония. 30.07.1990. В.Д. Бочкин; 'Юг Москвы. Разреженная растительность суховитой бровки пр.берега руч.Козловка у впадения в р. Битца близ ст.Битца Курской ж.д. 22.06.2005. В. Куваев:

Dactylorhiza incarnata (L.) Soo 'Москва. Рижская ж.д. 100м от пл. Рижского вокзала к пл. Дмитровская. Придорожная сырая луговина. 3 растения. 04.07.1991. В.Д. Бочкин; 'Москва, север. Савеловская ж.д. 800 м от пл. Окружная к пл. Дегунино. Болото у основания высокой ж.д. насыпи. Сырой луг вдоль болота. Колония. 22.06.1992. В.Д. 
Бочкин'; 'Москва, север. Савеловская ж.д. 1,9 км от пл. Окружная к пл. Дегунино. Болото у основания ж.Д. насыпи. Несколько десятков растений. 22.06.1992. В.Д. Бочкин' (МНА).

Eryngium planum L. 'Москва, по насыпи ж.д. между станциями Текстильщики и Люблино. 07.05.1980. М.С. Игнатов'; 'Москва, Шмитовский пр., склон насыпи Окружной ж.д. Одно растение. 06.08.1981. А.Н. Швецов'; 'Москва, Курская ж.д., около ст. Люблино в районе Люблинских прудов, в лесополосе, по опушке. Колония. 09.06.1987. В.Д. Бочкин; 'Москва, северо-запад. Рижская ж.д., 1,5 км от пл. Тушино к пл. Покровско-Стрешнево. (возле пересечения с Волоколамским шоссе). Луговина по склону высокой ж.д. насыпи. Много. 08.08.1991. В.Д. Бочкин:

Fragaria viridis (Duch.) Weston 'Москва, Казанская ж.д. 100 м от пл. Вешняки в сторону пл. Плющево (к Москве). Возле автомобильной эстакады. Вдоль ж.д. полотна. Придорожная луговина. Колония. 16.05.1989. В.Д. Бочкин'; 'Москва, Октябрьская ж.д., 300 м от пересечения с ул. Дыбенко к пл.Левобережная. Вдоль ж.д. По склону ж.д. Колония. 25.07.1990. В.Д. Бочкин; 'Москва, юг. Павелецкая ж.д. 1км от пл. Нижние котлы к пл.Коломенское (возле пересечения с Варшавским шоссе). Придорожная луговина. По склону глубокой ж.д. выемки. Колония. 17.06.1991. В.Д. Бочкин;; 'Москва, Рижская ж.д., 4000 м от пл. Дмитровская к пл. Гражданская. Луговина по склону ж.д. насыпи. Большая колония. 04.07.1991. В.Д. Бочкин؛

Iris pseudacorus L. 'Москва, ст. Кусково Горьковская ж.д., между рельсов старой ветки по которой давно уже не ходят поезда. Весьма крупный куст. 13.06.1980. М.С. Игнатов“; 'Москва, Октябрьская ж.д., 1,5 км от пл.Ховрино к пл.Левобережная. Заболоченный придорожный кювет. (около пересечения с Малой окружной ж.д.). 25.07.1990. В.Д. Бочкин'; 'Москва, Рижская ж.д. 200 м от пл. Рижского вокзала к пл. Дмитровская. Заболоченная придорожная луговина. Колония. 04.07.1991. В.Д. Бочкин:

Polygonum bistorta L. 'Москва, север, Савеловская ж.д., 2,2 км от пл. Окружная к пл. Дегунино. Болото у основания ж.д. насыпи. Большая колония. 22.06.1992. В.Д. Бочкин; 'Москва, север, Савеловская ж.д. 900 м от пл. Окружная к пл. Дегунино. Болото у основания ж.д. насыпи. Колония. 22.06.1992. В.Д. Бочкин.

Steris viscosa (L.) Rafin. 'Москва, Ярославская ж.д., 2 км от пл.вокзала к пл. Москва. Луговина по склону ж.д. выемки. Несколько растений. 20.06.1990. В.Д. Бочкин'; 'Москва, Юг. Курская ж.Д., 100 м от пересечения с Павелецкой ж.д. к пл. Покровская. Луговина по склону ж.д. выемки грузовой колеи. Одно растение. 19.06.1991. В.Д. Бочкин'; 'Москва, юг. Курская ж.д. 700 м от ст. Царицыно к пл. Покровская. Грузовая колея. Луговина по склону ж.д. выемки. В массе. 20.06.1991. В.Д. Бочкин:

Trollius europaeus L. 'Москва, север, Савеловская ж.д., 1,2 км от пл.Окружная к пл. Дегунино. У основания ж.д. насыпи. Сырой луг. Колония. 22.06.1992. В.Д. Бочкин'

Таким образом, в Москве 7 \% придорожных растений (34 из 480) классифицируются как редкие или довольно редкие виды, и некоторые дорожные откосы должны рассматриваться как объекты особого внимания, например, насыпь с лугово-степной растительностью перед железнодорожной станцией Бутово, на которой редкие 
виды удерживаются довольно долгое время. Поскольку в Москве даже мозаичные луговые сообщества встречаются крайне редко, необходимо задействовать все меры поддержания остатков этих природных фитоценозов, исчезновение которых является главной угрозой снижения естественного биоразнообразия. Остро стоит задача разработки мер для сохранения на обочинах дорог аборигенных видов, вопреки сложившейся практике застилания откосов рулонными газонами. Доля природных луговых видов может быть увеличена при подходящем режиме скашивания и отказа от использования гербицидов, а также, возможно, за счет искусственного подсева семян аборигенных растений. В условиях мегаполиса такой подход явится единственно возможным способом повышения экологического значения придорожных местообитаний, которые смогут принять на себя функцию экологических коридоров для аборигенных видов не только растений, но и насекомых и даже, возможно, животных.

\section{Выводы}

На откосах железных дорог г. Москвы отмечено 34 вида, включенные в «Красную книгу города Москвы», причем двум из них Botrychium lunaria и Allium angulosum присвоена категория 0, а четырем Antennaria dioica, Nonea pulla, Dactylorhiza fuchsii и Thymus marschallianus - категория 1. Некоторые «железнодорожные популяции» редких видов довольно устойчивы: и Allium angulosum на луговине возле ж.д станции Бойня, и Thymus marschallianus на ж.д. насыпи с луговостепной растительностью перед ж.д станцией Бутово существуют уже более 20 лет. Рекорд установил Thymus $\times$ loevyanus: этот гибридогенный таксон растет в одном и том же местообитании - на ж.д. насыпи с луговостепной растительностью перед ж.д станцией Бутово с 1946 года (более 65 лет).

Таким образом, в условиях крупных городов железнодорожные откосы могут восполнять отсутствие подходящих местообитаний как для естественной растительности в целом, так и для редких и исчезающих видов растений.

\section{Благодарность}

Исследование выполнено в Центре коллективного пользования «Гербарий Главного ботанического сада им. Н.В. Цицина Российской академии наук» в рамках ГЗ ГБС РАН (№118021490111-5) при частичной финансовой поддержке Российского фонда фундаментальных исследований (проект № 18-04-00411) и Народной стипендиальной программы Словацкой Республики.

\section{Литература}

ALLEM, A.C. 1997. Roadside habitats: a missing link in the conservation agenda. In Environmentalist, vol. 17, p. 7-10.

BARINOV, A.V. 2017. Problemy` razrabotki sistemami upravleniya bazami danny`kh po chuzherodny`m vidam rastenij. Izuchenie adventivnoj i sinantropnoj flor Rossii i stran blizhnego zarubezh ya: itogi, problemy`, perspektivy`. Mat-ly` V mezhdun. nauch. konf. [Problems of development the control system for database of alien plants. Study of alien and sinantropic floras of Russia and adjacent countries: results, problems, prospects]. In Materials of $V$ international conference. M.; Izhevsk : Institut of computer study, p. 26-29 [In Russian]. 
CALE, P., HOBBS, R. 1991. Condition of roadside vegetation in relation to nutrient status. In Nature conservation. Chipping Norton : Surrey Beatty et Sons, p. 353-362.

HARRINGTON, J.A. 1994. Roadside landscapes. Prairie species take hold in Midwest rights-of-way. In Restor. Manage. Notes., vol. 12, p. 8-15. http://dx.doi.org/10.3368/er.12.1.8

IGNATOV, M.S., MAKAROV, V.V., CHICHEV, A.V. 1990. Konspekt flory` adventivny`kh rastenij Moskovskoj oblasti. Floristicheskie issledovaniya v Moskovskoj oblasti [Conspect of flora of adventive plants in the Moscow region]. In Floristic researches in the Moscow Region. M. : Nauka, p. 5-105 [In Russian].

IVANOVA, N.V. 2008. K voprosu izucheniya flory` Kujby`shevskoj zheleznoj dorogi (v predelakh g. Samara). Samarskaya Luka: problemy` regional'noj i global’noj e`kologii [On the study of the flora of the Kuibyshev Railway (within Samara)]. In Samarskaja Luka: problems of regional and global ecology, vol. 17, no. 3(25), p. 600-606 [In Russian].

JANDOVÁ, L., SKLENÁŘ, P., KOVÁŘ, P. 2009. Changes of grassland vegetation in surroundings of new railway flyover (Eastern Bohemia, Czech Republic). Part I: Plant communities and permanent habitat plots. In Journal of Landscape Ecology, vol. 2(1), p. 35-56. http://dx.doi.org/10.2478/ v10285-012-0013-4

JEFFERSON, E.J., LODDER, M.S., WILLIS, A.J., GROVES, R.H. 1991. Establishment of natural grassland species on roadsides of southeastern Australia. In Nature conservation. Chipping Norton : Surrey Beatty et Sons, p. 333-339.

KHUSAINOVA, S.A. 2016. Flora i rastitel'nost' zheleznodorozhny'kh nasy'pej Kujby'shevskoj i YuzhnoUral 'skoj zhelezny 'kh dorog (v predelakh respubliki Bashkortostan) : avtoreferat dis.... kand. biol. nauk [Flora and vegetation of railway embankments of Kuibyshev and South Ural railways (within the Republic of Bashkortostan) : Abstract of the dissertation... Cand. Biol. Science.] Ufa., 18 p. [In Russian].

KOPECKÝ, K., HEJNÝ, S. 1974. A new approach to the classification of anthropogenic plant communities. In Plant Ecol., vol. 29, p.17-20. http://dx.doi.org/10.1007/BF02390892

KRASNAYA KNIGA GORODA MOSKVY' [RED BOOK OF THE MOSCOW CITY]. 2011. Government of Moscow. Department of Nature Management and Environmental Protection of Moscow; B.L. Samoilov, G.V. Morozov (editor). $2^{\text {nd }}$ ed., Pererab. and additional. M. 927 p. [In Russian].

MAJOROV, S.R., BOCHKIN, V.D., NASIMOVICH, JU.A., SCHERBAKOV, A.V. 2012. Adventivnaya flora Moskvy ' i Moskovskoj oblasti [Alien flora of the Moscow city and Moscow district]. Moskva : KMK, 412 p. [In Russian].

PARR, T.W., WAY, J.M. 1988. Management of Roadside Vegetation : The Long-Term Effects of Cutting. In Journal of Applied Ecology, vol. 25(3), p. 1073-1087.

PENONE, C., MACHON, N., JULLIARD, R., LE VIOL, I. 2012. Do railway edges provide functional connectivity for plant communities in an urban context? In Biological Conservation, vol. 148, p. 126-133.

RYBAKOVA, I.V. 2008. Flora zheleznodorozhny'kh nasy’pej yuzhnoj chasti privolzhskoj vozvy`shennosti : avtoreferat diss.... kand. biol. nauk [Flora of railroad embankments in the southern part of the Volga Upland : dissertation these]. Saratov. 18 p.

SCHAFFERS, A.P., SÝKORA, K.V. 2002. Synecology of species-rich plant communities on roadside verges in the Netherlands. In Phytocoenologia, vol. 32(1), p. 29-83.

SKVORCOVA, I.V., BEREZUCKIJ, M.A. 2008. Flora zheleznodorozhny`kh nasy`pej Yuzhnoj chasti Privolzhskoj vozvy`shennosti [Flora of railroad embankments in the Southern part of the Volga Upland]. In Povolzhsky Ecological Journal, vol. 1, p. 55-64 [In Russian].

TIKKA, P.M., HÖGMANDER, H., KOSKI, P.S. 2001. Road and railway verges serve as dispersal corridors for grassland plants. In Landscape Ecology, vol. 16, p. 659-666. http://dx.doi. org/10.1023/A:1013120529382

VINOGRADOVA, YU.K., BOCHKIN, V.D., MAJOROV, S.R., TEPLOV, K.JU., BARINOV, A.V. 2017. Istoricheskaya flora zheleznodorozhnogo uzla moskovskogo megapolisa (v graniczakh do 2012 goda) [Historical flora of Moscow's Railway Junction (until 2012)]. In Hortus Botanicus, vol. 12, p. 77-106. http:// dx.doi.org/10.15393/j4.art 2017.3402 [In Russian]. 